\title{
Keeping a Good Idea Alive: Chamber Music in Brisbane in the 1950s and 1960s
}

\author{
Peter Roennfeldt \\ p.roennfeldt@griffith.edu.au
}

As many musicians would attest, small ensemble collaboration provides very special rewards. Chamber music performance has rarely been a viable full-time career aspiration, but this has not deterred many Australians from devoting huge amounts of energy to its survival. However, as a flexible medium with interchangeable personnel and diverse performance contexts, it is difficult to find a 'through line' that links these disparate activities over time. As an amalgam of disparate entities, chamber music is rarely accorded the same recognition as larger ensembles such as orchestras, choirs, bands and theatrical-operatic companies.

In two earlier articles, I traced chamber music activities in Queensland up to 1900 and 1950 respectively. ${ }^{1}$ While some continuities with the later period are detectable, discontinuities are just as pronounced, due to the predominantly freelance nature of the profession, and the socio-economic landscape that determines an ensemble's longevity or otherwise. In Brisbane, the Jefferies family and their associates ensured that chamber music was a fixture across the half-century prior to World War II. Astonishingly, despite wartime challenges, two levels of government subsequently sponsored permanent entities, namely the Brisbane City Council Civic Chamber Music Concerts from 1941, and the Queensland State String Quartet during 194452. This article traces Queensland's chamber music after the Queensland State String Quartet's demise until the next major turning point, in 1972.

\section{Changing Priorities for Arts Funding in the Early 1950s}

While the Brisbane City Council concerts continued until the end of the twentieth century, changing priorities saw the state government permanently disband its string quartet. Meanwhile, the Conservatorium campaign gained considerable momentum, while the State Opera Scheme, which toured statewide, attracted official support from 1949 until 1953. State government patronage of professional music-making in the 1950s centred almost exclusively on the Queensland Symphony Orchestra (QSO), established in 1947 with assistance from the Brisbane City Council, but primarily under the federal management of the ABC.

But what of chamber music? Had the rhetoric about giving 'a lead to the rest of Australia'2 merely vanished after eight years of sterling effort by the Queensland State String Quartet, which played to combined audiences of 100,000 annually? Was it a case of 'bigger is better' with the QSO as the solitary flagship arts 
organisation to survive after the early 1950s? The final mention of the potential continuation of the State String Quartet was in 1953, by which time the major community focus was the much-discussed Conservatorium. ${ }^{3}$ Lobbying also ensued on behalf of various operatic and theatrical companies, ${ }^{4}$ but in the absence of a high-profile ensemble, the relatively modest needs of chamber music were overridden.

A possible explanation for the revision of arts funding priorities was the abrupt leadership change of early 1952. When Premier Hanlon died unexpectedly in January, Vince Gair assumed the role, and there was some expectation that he might follow his predecessor's lead in supporting the arts. ${ }^{5}$ In the absence of a cultural affairs portfolio, which only appeared in 1968 , the de facto location for the arts was somewhere within the Department of Public Instruction (renamed Education from 1957). Following the visionary tenure of Director-General L. D. Edwards, who fostered the arts as integral to well-rounded education, leadership passed to H. G. Watkin. However, the depth of his musical knowledge was frequently questioned by those he supervised. ${ }^{6}$

Notwithstanding the ongoing benefits of the Brisbane City Council's monthly chamber music concerts, the loss of the Queensland State String Quartet was widely felt. Alternatives would however soon arise from within the much expanded pool of resident musicians, courtesy of the QSO/ABC. In addition to being the state's premier orchestra, the QSO also became a de facto incubator of the next wave of chamber music activity. During the 1950s, QSO players were not employed on the same full-time basis as their southern counterparts, so those seeking additional performance opportunities had capacity to create chamber ensembles. As cited in the aforementioned article, examples included the Amadeus Trio and Quintet led by clarinetist George Lancaster, the Melodia Trio with pianist Rees Morgan, and the Brisbane Concert Trio with pianist Hilda Woolmer. However, the precedent of the State String Quartet and its entrepreneurial subscription series suggested that something of greater significance could be envisaged. The re-creation in Queensland of a major string quartet seemed entirely appropriate and feasible.

\section{A Permanent String Quartet - Musica da Camera}

The next iteration of Queenslanders' aspiration for a permanent string quartet, first voiced in the 1870 s, ${ }^{7}$ was the Musica da Camera Quartet. Like Sydney-based Musica Viva, it instigated a concert series that perpetuated its vision, even after the founding ensemble disbanded.

Comprising QSO players Leonard Dommett, Ena Wooderson, Thomas Mullins and Anthony Sorgato, Musica da Camera first presented home concerts during 1954. The debut at the Curro family's New Farm home entertained about fifty listeners, while the second musicale in nearby Marlborough Flats, featuring clarinetist colleague Donald Westlake, attracted a bigger audience. It was noted that domestic venues 'ideally create the intimate atmosphere desirable for the performance and appreciation of chamber music'. Audience involvement was also encouraged by inviting future repertoire suggestions. ${ }^{8}$ This ensemble soon embarked on a public series supported by its own organising committee, in venues including the Teachers' Conference Hall, Gowrie Hall and the 4BH broadcast studio. Official status later attended the appointment of patrons, including Conservatorium director William 


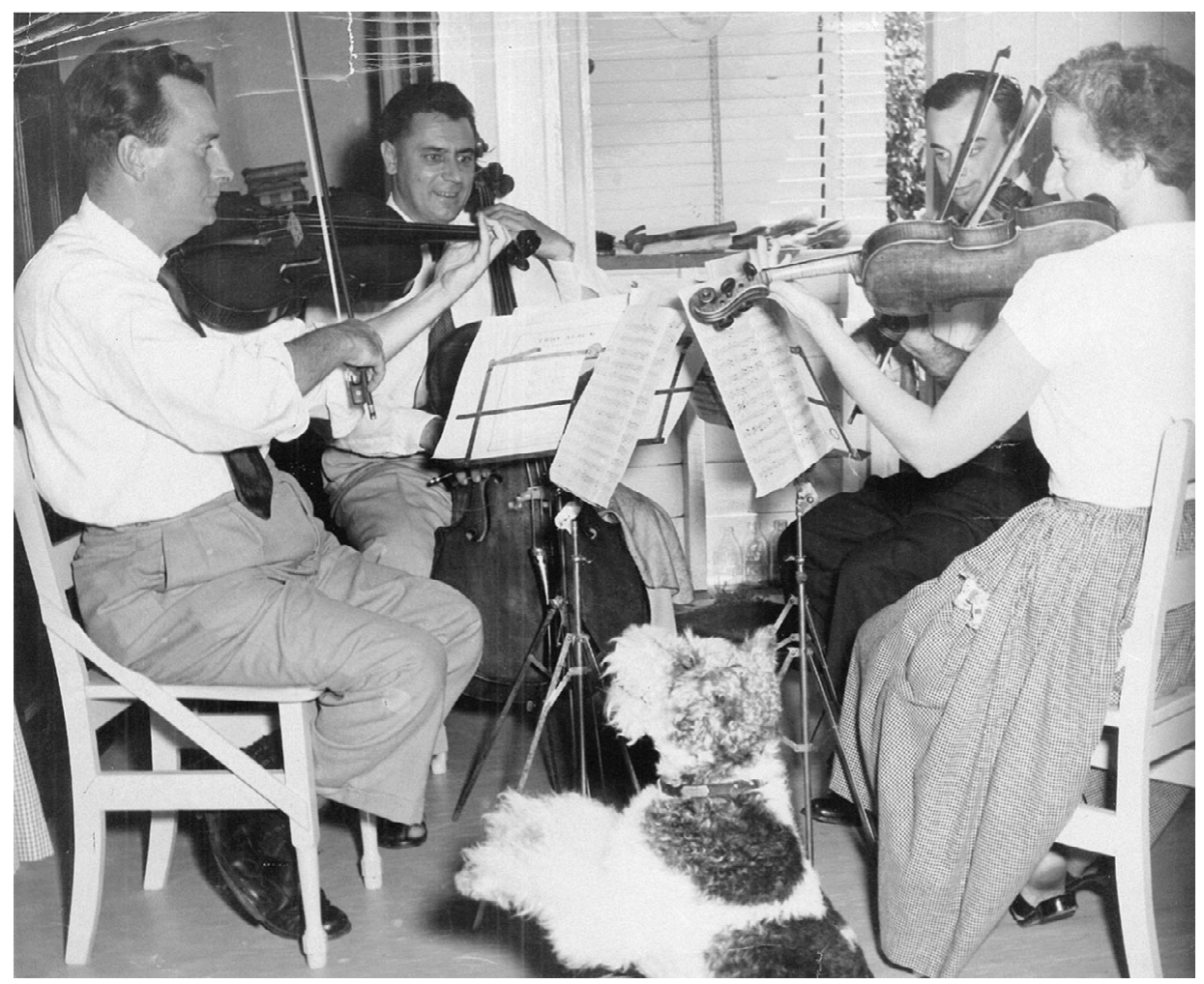

Musica da Camera string quartet in rehearsal c. 1955. From left: Leonard Dommett (violin), Anthony Sorgato (cello), Thomas Mullin (viola), Ena Wooderson (violin). Photographer and source unknown.

Lovelock and QSO conductor Rudolf Pekarek, while the ABC supported its players’ appearances in this capacity 'by permission'.

After a guest appearance for the Brisbane City Council series in mid-1955, critics noted that 'a good performance was to be expected ... [from] such experienced players', who presented Beethoven and Dvořák. ${ }^{9}$ Musica da Camera's growing profile was acknowledged in its 'consistently good work' in giving 'greater interest in chamber music to our general public'. ${ }^{10}$ From 1957, the Conservatorium Hall in South Brisbane became a regular venue 'through the gracious permission of the Department of Education', ${ }^{11}$ though at first marred by a 'traffic obbligato from outside, punctuated by solos by noisy trams'. Nevertheless, the performance showed that the quartet - now including violist Philip de Boers - was 'within measurable distance' of comparison with overseas ensembles in their rendition of Schubert's Death and the maiden. ${ }^{12}$ QSO clarinetist Barbara Lockwood also appeared in the Brahms Quintet for their 1957 series finale, when it was noted that Musica da Camera was 'one of Brisbane's finest musical assets ... the city has a resident quartet of importance'. ${ }^{13}$ Again, the late nineteenth century community aspiration for chamber music excellence was articulated.

A similar formula persisted in 1958, with evidence of enterprise in the preponderance of recently composed works. Honegger's third quartet, 'allegedly 
in C major' and Barber's Dover Beach, in its Australian première with guest baritone James Christiansen, commenced the year in 'courageous' style. ${ }^{14}$ Similarly, the quartet's Debussy interpretation made it seem 'almost a recent work', while in Mozart's Dissonance, the players 'groped through the intensely disturbing opening to the sunlight beyond'. ${ }^{15}$ Due to Dommett's illness, their final recital introduced additional QSO colleagues, oboist Pauline Roberts and pianist Rees Morgan, in works by Gordon Jacob and Schumann respectively. Having commenced the year boldly, the Musica da Camera Quartet - in this instance, as trio plus associates - offered as its swansong 'good, hearty stuff' in a program of 'relatively light emotional weight'. ${ }^{16}$

\section{Musica Viva Society Establishes a Queensland Outpost}

Undoubtedly the major force in Australian chamber music since World War II has been Musica Viva. As an Austrian pre-war refugee from the Anchluss, Richard Goldner premiered an ensemble in late 1945, around which an entrepreneurial organisation developed. Sydney remained the organisation's headquarters, but the Musica Viva Players soon included tours to Brisbane. ${ }^{17}$ After the founding quartet disbanded in 1951, Musica Viva resurrected itself in 1955 with a circuit of southern states that expanded northwards the following year. Formed in early 1956, the Queensland committee needed financial underwriting to ensure the Pascal Quartet's visit. This was provided by founding patron T. J. Weedman, an arts-friendly businessman with a strong philanthropic record. ${ }^{18}$

While any survey of Queensland's chamber music must include Musica Viva, its survival here was not guaranteed. Despite ongoing cross-border collaborations and local sponsorship, Queensland was not initially central to Musica Viva's identity, as evident in historical accounts of its first half-century. Brisbane served as the organisation's northern outpost, and pioneering efforts were later recognised by life memberships conferred on several long-standing supporters. However, even the ex-Brisbanite Roger Covell, whose journalistic career developed concurrently with Musica Viva's rejuvenation, traces the national organisation's early history without reference to Queensland. ${ }^{19}$ Despite this historical silence, visiting ensembles presented under Musica Viva's auspices were enthusiastically welcomed by Queensland audiences and critics alike. Commentators repeatedly asserted its ongoing value, with statements such as 'our debt to Musica Viva continues undiminished'. ${ }^{20}$ Locally based performers were occasionally engaged as 'Australian content'. Significantly, all but three seasons during 1956-72 featured Australian ensembles, over half of which showcased Queensland musicians. Being selected was a significant honour, particularly with Musica Viva's growing profile as the world's largest chamber music organisation.

The inclusion of the first Queensland-based ensemble in 1957 was viewed as not merely a convenience, but an affirmation of high local standards. Critic Robert Dalley-Scarlett stated that, while not wishing to 'deprecate [sic] the featuring of visiting players .... it is time that we learnt to stand on our own feet ... in the Musica da Camera players we have a quartet which has now reached a stage when it can compare favourably with any other quartet available'. With Barbara Lockwood and Conservatorium piano lecturer Rex Hobcroft joining for Mozart and Brahms quintets, their Haydn Lark quartet had the 
greatest homogeneity, demonstrating 'the high art arising from playing as with one mind'. ${ }^{21}$ Similar comments accompanied the equivalent concert in 1958, which featured cellist Julie van der Klei and pianist Allen McCristal of the QSO/ABC, and baritone James Christiansen and pianist Judith Heck from the Conservatorium - 'it was a matter of pleasure that it was possible to find, locally, artists to measure up to the high standard which the Musica Viva Society has set'. ${ }^{22}$ Meeting growing audience expectations was a significant concern. By 1960, Musica Viva had already presented ensembles of the calibre of the Pascal, Parrenin, Smetana, Amadeus and Janacek quartets, among others. It was also asserted that Musica Viva and Musica da Camera 'were not rivals', as they focused respectively on 'international groups of international fame' and groups 'living in or near Brisbane'. ${ }^{23}$

A perennial challenge was the search for venues that matched both performers' and the audience's needs. After a 'well-attended' 1956 debut in Brisbane City Hall, ${ }^{24}$ the focus shifted to West End, where the 'out-of-town [Rialto] theatre [was] steadily becoming one of the city's most important musical centres'. ${ }^{25}$ During 1957 , the complete series returned to City Hall, but some concerts were only partially unsatisfactory. Whether it was the venue's 'spaciousness' or its notorious acoustics, or the fact that the Parrenin Quartet's 'faster movements ... were over accelerated for the size of the Hall, and consequently detail was somewhat blurred', ${ }^{26}$ ongoing popular demand required compromises. The Smetana Quartet, famous for performing completely from memory, 'drew a thousand strong audience' for its concert, which was denoted as making 'chamber-music history here'. ${ }^{27}$ Unfortunately, the City Hall's circular design did not suggest alternative configurations, such as were possible in Sydney Town Hall. There, the 'special Musica Viva seating plan' located performers in the body of the venue, thus minimising distances from listeners. ${ }^{28}$

Nearby Albert Hall soon became Musica Viva's chief Brisbane venue for all but the most popular visiting ensembles. Occasional outings to Lennons Broadbeach Hotel provided opportunities for non-metropolitan repeat programs, but this was a short-lived initiative in 1959. Despite some early successes, then branch president Malcolm Cameron stated that 'Musica Viva is still a frail infant, depending for its life on blood transfusions by sponsors', and reiterated that a solid subscriber base was paramount. Concurrently, Brisbane City Council concerts could 'attract audiences that fill the auditorium to capacity' — admittedly a lesser challenge in the smaller Lord Mayor's Reception Room. ${ }^{29}$

Musica Viva's repertoire was initially rather unadventurous. As Covell observes, this was due partly to a 'higher degree of cultural conservatism in an émigré group than in the society from which it departs'. ${ }^{30}$ He further notes that the relatively strong presence of Austro-Hungarian migrants in Sydney permitted a special place for Bartók's quartets, which were not complete novelties in Brisbane, due to the prior work of the Queensland State String Quartet. Allowing for the genre-specific needs of the Sydney Sinfonietta wind quintet playing Hindemith, Arnold and Nina Rota, or baroque programming by the Società Corelli chamber orchestra, very little non-mainstream repertoire was presented by visiting ensembles before 1960 . The Parrenin Quartet's Lyric Suite by Berg, with its 'acidulous atonality', received only 'polite applause', ${ }^{31}$ while the Amadeus Quartet's interpretation of Verdi's 'rarely heard' Quartet in E minor was strategically programmed between Mozart and 
Brahms standards. ${ }^{32}$ Diversification of repertoire and ensemble types became more common throughout the 1960 s.

\section{Musica da Camera Continues Without Its Founding Quartet}

Musica da Camera continued, but with different performers from 1959 onwards. Owing to health reasons and heavy commitments during the state's centenary celebrations, the founding quartet offered its 'regrettable resignation'. ${ }^{33}$ The Queensland Chamber Music Group of violinist-violist Gloria Foley, violinist John Curro and cellist Jiř́ Svoboda now became a resident ensemble, performing alongside guest artists. The review of their debut as a 'most capable trio' characterised by 'ardour, power, and full and spreading tone' within 'one of its most interesting and rewarding concerts' must have pleased Musica da Camera's organisers at this critical juncture. ${ }^{34}$ The trio was later joined by pianist James Thomas in an 'outstanding musical experience' with a Schumann trio, ${ }^{35}$ while the society 'broke fresh ground' in its inclusion of vocal items by the University Madrigal Group under Gordon Spearritt. ${ }^{36}$ Also appearing was the Una Morgan Trio, whose trademark Debussy sonata was performed with flautist Patrick Thomas and violist Philip de Boers. The first Musica da Camera season not to feature its namesake ensemble offered a completely different chamber music experience.

Reaffirming its objectives in 1960, Musica da Camera asserted the benefits of social interaction, presentation of both 'works well-known to many music-lovers, together with less familiar works of real musical interest' and its profiling of both 'a core of experienced players' while encouraging 'other performers including outstanding young players'. ${ }^{37}$ Concurrently, recent interstate exposure of Brisbanebased musicians at Musica Viva's Mittagong summer school had 'convinced Sydney critics and some of Australia's leading instrumentalists that chamber music of high quality is vigorously alive in Queensland'. Diverse repertoire choice was evident in Dohnányi's Serenade and Hindemith's Variations for clarinet and strings, and also tenor Peter Martin's presentation of Schubert's Die schöne Müllerin. ${ }^{38}$ Balancing this were piano trios and quartets by Mozart, Fauré and Dvořák, performed with visiting artist Beryl Potter in the season finale. On that occasion, Lovelock observed that the hall 'may soon prove insufficiently large', while querying the near-absence of tertiary students. ${ }^{39}$ The resident trio also expanded briefly, with Max Muller's appearance in Borodin's quartet 'with the famous Nocturne'. 40

Fostering of new music and local composers emerged as a significant theme during 1961. The involvement of Czech violinist Viliam Simek facilitated some 'initiative' in the Australian première of Karl Schiske's expressionist Sextet. ${ }^{41}$ Contemporary English trends featured in the local première of Jacob's Six Shakespearian sketches (1946), ${ }^{42}$ E. J. Moeran's String Quartet in Eb (published 1956), which was 'quite an outstanding achievement for the society' and the ensemble led by Lyndal Edmiston. ${ }^{43}$ Artsongs by John Villaume were performed, while Georg Tintner interrupted a regional opera tour to attend the première of his Fugal moods for string trio. ${ }^{44}$ Similar trends were also seen in 1962, with Czech works by Dvořák and Martinů, Jacob's Clarinet quintet and the Sonata for unaccompanied violin by recently arrived Conservatorium lecturer Larry Sitsky, which 'exploits a type of writing akin to Bartók' ${ }^{45}$ 
Musica da Camera's options expanded further when a sizeable entourage of emerging string players accompanied violinist Jan Sedivka to Brisbane after his appointment to the Conservatorium staff in 1961. Other newcomers were Theodore Lazaroff and Joan Farrow, both well known as long-standing QSO members. Lazaroff's newly formed Queensland String Quartet presented an entire program without supporting artists, performing Sibelius' Voces intimae. Several other QSObased ensembles, including two former Queensland State String Quartet members George White and Donald Scotts, also assisted in broadening the organisation's profile. While Haydn, Mozart, Beethoven, Brahms and Dvořák appeared regularly, less familiar works by Malipiero, Bax, Khachaturian, Arensky and Busoni produced a remarkably rich series during 1963. The Queensland Chamber Group was not universally acclaimed, but when augmented by Conservatorium director Basil Jones for the Fauré quartet, 'the chance of hearing such unusual music once in a while' was commended. The season's 'fitting climax' was a Brahms quartet featuring pianist John Stehbens. ${ }^{46}$

\section{Pro Musica Trio and Quartet}

A rift soon occurred in Brisbane's musical world, ${ }^{47}$ with the result that most musicians associated with Sedivka ceased appearing for Musica da Camera. Foley's ensemble strategically repositioned itself, first as the Musica da Camera Trio, signifying its 'in residence' status, and finally as the Pro Musica Quartet. Although this was not a completely new lineup, it enhanced the society's identity. Its inclusion in a Musica Viva series also gave 'acknowledgement of its high standing'. ${ }^{48}$

Classic and modern composers continued to coexist happily in programs, with quartet repertoire including Smetana's From my life, Haydn's Emperor, and Ravel, but the expanded ensemble, including Basil Jones and George Farrell, took some time to consolidate. Greater things were predicted with the arrival of Ladislav Jasek, another eminent Czech musician who succeeded Sedivka. Pro Musica's debut with Jasek as leader in mid-1966 was 'highly creditable', their interpretation of Shostakovich and Brahms being 'the fruit of sincere and concentrated collective thought'. ${ }^{49}$ By season's end they were considered 'a well balanced and well integrated combination', with 'plenty of warmth' and 'full-blooded' tone in their playing. ${ }^{50}$

The Pro Musica Quartet soon lost momentum, however, despite contributing to 'the best concert [Musica da Camera] have ever given us' in early 1967, which 'promised well for the future of chamber music in Brisbane'. On that occasion Rodney Jacobsen in Brahms shared the honours with the duo of Jasek and Nancy Weir, whose memorised Franck Sonata 'fully deserved the unusually warm applause it received from a crowded audience'. ${ }^{51}$ Musica da Camera's 'enterprise' saw a diversification into non-string repertoire, particularly when the Laiton Brass Ensemble traversed five centuries from Gabrieli to newly composed repertoire. ${ }^{52}$ Similarly, a sonata program including Prokofiev by Jasek and Weir demonstrated the oft-cited political point that local musicians 'have nothing to fear in comparison with some of our visiting artists' ${ }^{53}$ After having regained for Musica da Camera the stability of a resident quartet, Gloria Foley's contribution ceased immediately upon the death of her husband Jiř́ Svoboda in 1968. Despite losing two musicians 
who played a central role for more than a decade, Musica da Camera reinvented itself by adopting other ensemble types as mainstays.

\section{Music Viva in the 1960s}

During the 1960s, Musica Viva's seasons expanded to five concerts annually, though the Australian component was increasingly selective. Comprising QSO players Donald Scotts, Theodore Lazaroff, Philip de Boers and Julie van der Klei, the newly formed Paragon Quartet featured twice, achieving critical acclaim for presenting lesser known repertoire by Walton, Respighi and Kodály. ${ }^{54}$ Also recently arrived, the piano duo of Max Olding and Pamela Page performed Margaret Sutherland's recent works, quite possibly a 'first' for Musica Viva in Queensland in the presentation of a living Australian composer. The only other Australian repertoire was George Dreyfus's Galgenlieder, also by locals, the Aulos Ensemble. Were it not for these modest contributions by Queenslanders, Musica Viva during the 1960s in Brisbane would have been exclusively 'non-local', both in the origins of its ensembles and its repertoire.

While string quartets still dominated, some novel excursions expanded Musica Viva's offerings nationally, particularly through the expanded format of a chamber string orchestra. After the precedent of Società Corelli in 1960, chamber orchestras appeared regularly in Brisbane courtesy of the Adelaide Festival, including Die Kammermusiker from Switzerland, the Jerusalem Chamber Orchestra and the Academy of St Martin-in-the-Fields. Also leavening the mix were the Bath Festival Ensemble, whose Messiaen Quatuor pour la fin $d u$ temps was probably a local première in 1968, and the groundbreaking Les Percussions de Strasbourg in 1971. The latter also presented the first Australian work commissioned by Musica Viva for an international ensemble - Peter Sculthorpe's How the stars were made. That impressive 'happening' showed how diverse chamber music could be. ${ }^{55}$ Apart from these forays, Musica Viva's repertoire remained focused on Viennese classicists and their nineteenth-century successors, a smattering of modern Eastern Europeans including Bartók and Shostakovich, some pre-World War I French works and, most rarely, a Britten work.

Venue choice and the audience experience were also significant factors, as only those concerts certain to attract large audiences were presented in City Hall. Apart from 1963, this occurred but once annually, with all other events in Albert Hall, Brisbane's second inner-city venue. This scenario ceased in 1969, when Albert Hall was demolished to provide space for the new State Government Insurance Office (SGIO, later Suncorp) building. With a 600-seat auditorium, proscenium and pit, the SGIO Theatre was unsatisfactory for concerts, so it was only used twice. The newly commissioned Brisbane Grammar School Centenary Hall became Musica Viva's sole venue from 1970 to 1972 , a necessary move as growing audience demand made good use of its 1,000-seat capacity. On at least two occasions in 1970 , record attendances were noted, with the summation that this was 'the best series of concerts yet sponsored by Musica Viva, made all the more satisfying by the unusually large and enthusiastic audiences' ${ }^{56}$ During 1971, the Academy of St Martin-in-the-Fields even saw Centenary Hall 'packed to suffocation ... and a large number were turned away'. ${ }^{57}$ 


\section{Musica Viva Younger Group}

Audience development was another priority for Musica Viva during the 1960s. Already in 1955 the Sydney branch's Younger Set had achieved instant success. Whether it was the novelty of informal settings, or the emphasis on a youthful demographic, very soon 'the problem had changed from one of creating interest in chamber music to one of finding homes large enough to accommodate the ever increasing audience', which soon exceeded two hundred! ${ }^{58}$ The equivalent Queensland venture likewise achieved overnight popularity. When the Musica Viva Younger Group formed in 1961, its first musicale at the Perry family's Yeronga residence attracted about a hundred listeners, who 'sat happily on the floor'. ${ }^{59}$ The venture was commended for breaking down age barriers and preconceptions, and for providing an entrée to people from 'all walks of life', and also from beyond Brisbane. ${ }^{60}$

The number of Younger Group events, with low-cost formats offering considerable flexibility, quickly exceeded Musica Viva's public series. Performance-based events alternated with workshops, providing an educational focus for tertiary music students and non-professionals alike. Conservatorium students were prominent, and some events later took place on campus, including its first public concert in 1971, which 'attracted a large and enthusiastic audience'. ${ }^{61}$

By then the Younger Group had a much-enhanced profile due to a short-lived series of festivals. The first Autumn Music Festival in 1968 showcased the Laiton Brass Ensemble, American Brass Quintet, Aulos Wind Quintet and a trio comprising Nancy Weir, Ladislav Jasek and Hans Gyors, altogether 'something of a gargantuan feast' with up to 150 attending. ${ }^{62}$ New music also featured, with Colin Brumby and William Lovelock as composers-in-residence. The 1969 event included the Sydney String Quartet, but the largest undertaking was in 1970 at the Gold Coast, when the visiting Austral Quartet presented the Australian première of Sculthorpe's String quartet no. 8 , in the composer's presence. In addition to well-known local ensembles, a multi-arts component with sculptor Kevin Brereton and poet Rodney Hall was also included. ${ }^{63}$

The Musica Viva Younger Group also encouraged performance excellence from among its membership. For example, at its 10th annual concert in 1971, the Margot Perry memorial prize was awarded to Conservatorium oboe student Jeffrey Crellin. After more than a decade of being 'an integral part of the city's musical life', the Younger Group continued into the 1970s, but without the same pioneering zeal. According to Rodney Jacobsen, the obvious success of the Gold Coast festival caught the attention of Musica Viva's head office, but with ramifications that resulted in a turnover of organisational personnel. ${ }^{64}$

\section{Early Music}

Both Musica da Camera and Musica Viva facilitated 'early music' - that is, historically informed performance of repertoire mostly composed before 1800. At the time, this usually meant a 'period' keyboard, but not yet authentic versions of other instruments. As early as 1960, a spinet was heard at Musica da Camera, when Colin Brumby and Marissa Bartoldin performed a Scarlatti cantata, ${ }^{65}$ while later programs included Telemann and particularly Purcell. In 1964, 'the real Purcell ... the daring harmonic innovator' provided 'the gems of the evening', but even the 
'strength and urgency' heard in his Chacony 'deserved more than the lukewarm applause $\ldots$ bestowed on it'. ${ }^{66}$

Once the Conservatorium acquired its harpsichord in 1964, possibilities expanded further. Repertoire diversification included seventeenth-century madrigals by Monteverdi, when Peter Martin's New Elizabethan Singers were accompanied by Una Morgan's 'invariably discreet' continuo playing. ${ }^{67}$ Subsequently, J. S. Bach's Musical offering was an 'absorbing experience', ${ }^{68}$ also notable because of the inclusion of newly appointed University of Queensland Professor Noël Nickson as violist, and possibly the only harpsichord performance ever given by Nancy Weir. Jean Jacobsen was the more regular harpsichordist, both in baroque repertoire and contemporary works by composers including Gordon Jacob. ${ }^{69}$ The Aulos Wind Ensemble occasionally profiled French composers such as Rameau, while the Baroque Wind Ensemble's repertoire was chosen mostly from the later eighteenth century. In addition, the recently formed Jubilate Singers gave lively performances of Renaissance motets and secular works, thus extending Musica da Camera's repertoire even further back to around 1500. Their 'excellent feeling for differentiation in style' between Palestrina, Josquin, French chanson composers and the Elizabethan madrigalists was praised in $1971 .^{70}$

Meanwhile, Musica Viva audiences became accustomed to hearing at least one early music group per year, commencing with the Deller Consort in 1964. The double precedent of both a vocal ensemble and pre-classical repertoire was greeted with foreboding even in Sydney, but nevertheless succeeded with record attendances. Brisbane likewise reaped benefits, particularly when the Consort returned in 1967, eliciting rave reviews for 'continuous and concentrated artistry ... as near to perfection as is possible in this imperfect world', even in Gesualdo's tortured chromaticisms and Debussy's Trois chansons. ${ }^{71}$ Two years later, a natural limit was reached with both the Early Music Quartet and the Purcell Consort of Voices appearing in a single season, and repertoire extending even to the thirteenth century, within Syntagma Musicum's 1971 concert. The trend of complementing instrumental concerts with occasional vocal programs, and also classical-romantic repertoire with that of earlier centuries, had 'certainly broadened many people's ideas on chamber music'. ${ }^{72}$

\section{Final Years of Musica da Camera}

For the first time since its inception in 1955, Musica da Camera presented its 1968 season without a resident string ensemble. Instead, several differently configured groups now featured regularly in successive seasons. For example, the Aulos Wind Quintet, whose key members were already familiar, quickly developed to the point of being engaged by Musica Viva in 1969. At their debut the previous year, both diversity of programming and 'great gusto' in modern works such as Hindemith's Kleine Kammermusik were well received. ${ }^{73}$ In comparison, the Una Morgan Trio was no newcomer, despite some personnel changes. Its program, juxtaposing 'rarities by well-known composers' alongside three moderns - Persichetti, Meulemans and Brumby - was cited as evidence of Musica da Camera continuing 'the tradition they have established of presenting programmes of interest and enterprise'. ${ }^{74}$

The 1968 season profiled the Laiton Brass Ensemble and the Music Makers string quartet. Both comprised leading QSO players, and the latter presented Schumann 
with Nancy Weir, who in turn regularly partnered violinists Ladislav Jasek and Josef Aronoff. Aronoff also established a flexibly configured Artemon Ensemble in 1972, performing 'especially interesting' cello-less trios with violinist Dene Olding and violist Elizabeth Morgan..$^{75}$ Other string-piano combinations featuring pianist Rhonda Vickers now appeared - with violinists Kerry Smith, whose Bartók second was 'masterly', ${ }^{76}$ and Pamela Bryce, whose Dohnányi sonata was 'tremendously rewarding. ${ }^{77}$ The sibling duo of pianist Bernice and violinist Wilfred Lehmann performed in 1972, when negative comments about the 'enthusiastic, but ... small' audience and the noticeable absence of Conservatorium students coloured what would be Musica da Camera's final series. Although its final concert had futurefocused aspects, particularly with Conservatorium and university student ensembles collaborating in a 'program of quality', this was to be a sunset rather than a new dawn for the organisation. ${ }^{78}$

Despite increasing competition for audiences, and the self-imposed limitation to local talent in comparison to the stellar array supplied by Musica Viva, Musica da Camera had continued to offer something unique and substantial. In 1969, its fifteenth season, it was noted that Musica da Camera 'can be relied on to offer programmes which are interesting, varied and unhackneyed' ${ }^{79}$ Such positive comments were matched by official recognition, through an inaugural arts grant under State Cultural Activities Director Arthur Creedy. ${ }^{80}$ Similar government assistance was also awarded to the Musica Viva Younger Group for its festivals.

During its eighteen-year existence, Musica da Camera had served multiple needs, offering a platform for resident ensembles and also promoting greater diversity of repertoire and instrumentation than Musica Viva initially provided. While several interstate tertiary institutions were spawning ensembles-in-residence, such as the University of Adelaide Wind Quintet and the Sydney String Quartet at the New South Wales Conservatorium, Queensland as yet lacked similar resources. Musica da Camera therefore contributed strongly to the public profile of the fledgling Conservatorium in enhancing its auditorium status as a major venue, and particularly in showcasing staff and alumni performers in over half the seventy concerts it presented.

\section{Regional Centres and Other Venues}

It is incorrect to infer from this discussion that Brisbane was the only chamber music centre in Queensland during the post-war decades. In several regional cities, local and visiting ensembles provided opportunities for audiences to explore this repertoire, even if their frequency was limited. Some examples in the early 1950s include lecture-recitals presented under the auspices of the Board of Adult Education in Rockhampton and Townsville. The Rockhampton Harmonic Trio, comprising violinists Alfred and Shirley Unwin and pianist Romilly Millett, surveyed eighteenthcentury composers, including a 1950 Handel program, which 'met with unqualified approval of the large audience'. ${ }^{81}$ Already in mid-1952 the recent demise of the State String Quartet was being noted there, highlighting the need for this local ensemble to 'keep alive' a type of music that is 'not often performed'. ${ }^{82}$

In Townsville, the Kennedy Chamber Music Players presented regular lecturerecitals for the Adult Education Centre. Their diverse programs were much praised, with critics stating that while "chamber music is rarely heard even in the capital 
cities', the work of Keith and Elizabeth Kennedy had 'served to keep Townsville high in the world of culture'. ${ }^{83}$ While such claims might appear parochial, evidence for 1951 exists of a sonata by Delius, a composer rarely if ever programmed in Brisbane's chamber music concerts to that time. A 1954 presentation featured movements from Beethoven, Borodin and Dvořák, ${ }^{84}$ while a program in honour of the Royal visit featured various Masters of the King's Music, included selections by the current incumbent Arnold Bax. ${ }^{85}$ Towards the end of the period under discussion here, a Townsville Chamber Music Society was formed in 1968. Its debut recital, presented by clarinetist David Shepherd, pianist Rhonda Vickers and violist John Curro, was an 'unqualified success' and 'the most memorable musical event' that year. As frequently observed in metropolitan contexts, the emergence of a chamber music support structure was hailed as 'a major contribution to the cultural life of the city'. ${ }^{86}$

Various other Brisbane-based chamber ensembles also toured regionally. The Gloria Foley Trio 'supplied a well satisfied audience with intelligent and well played music' for the Warwick Music Association in $1958 .{ }^{87}$ Toowoomba also attracted numerous ensembles, in addition to Foley's Chamber Music Players, whose program of Mozart and Beethoven 'was well received by a large audience'. ${ }^{88}$ The 1960s was particularly active, with the Toowoomba Chamber Music Society presenting series that mirrored the repertoire diversity of Musica da Camera, and also benefited from collaborations with Musica Viva. The 1965 season featured a trio comprising Conservatorium staff pianist Larry Sitsky and violinist Jan Sedivka with cellist Sela Trau, the Pro Musica Trio and the Paragon Players, all from Brisbane. By arrangement with Musica Viva, the Prague and Hungarian Quartets also appeared in the mid-1960s. The Sitsky-Sedivka trio was a welcome inclusion, its program of Bloch, Busoni and Dvořák being presented by 'players of unusual calibre'. ${ }^{89}$ A 1966 concert, featuring Pamela Bryce and Rhonda Vickers in Beethoven and Stravinsky, was shared with the Queensland University Society for Renaissance Music, again demonstrating a broadening understanding of chamber music beyond predictable options. ${ }^{90}$

This discussion would also not be complete without reference to the Brisbane City Council civic concert series, which continued as before. Its profile had waned since the 1940s and 1950s, when significant audience and critical attention confirmed this as the major platform for chamber music, apart from the Queensland State String Quartet series. ${ }^{91}$ Several ensembles nurtured by the BCC concerts remained active in the 1960s, such as the Brisbane Trio with Hilda Woolmer. A later innovation was venue experimentation in the use of City Hall's foyer, with audience members encouraged to bring cushions if desiring to sit on the marble staircase. The Laiton Brass Ensemble's concert would certainly have tested its vibrant acoustics, but also expanded audience perceptions by the inclusion of Renaissance repertoire. ${ }^{92}$

Opportunities also expanded with the advent of the University of Queensland concert series from 1966 onwards. Ensembles such as the Pro Musica Quartet and the Weir-Jasek duo gave repeat performances of their Musica da Camera programs, while newer groups also featured. A significant occasion was the 1968 concert that inaugurated the Sunday afternoon series, featuring the string trio of Jasek-CurroGyors in Beethoven, complemented by a 'meaty' duo sonata composed by the University's Professor of Music, Noël Nickson..$^{93}$ Together with weekly lunchtime 
concerts, the University of Queensland complemented inner-city chamber music offerings, though solo recitals tended to dominate there at first.

\section{2: A Turning Point and a Centenary}

At the end of 1972, Musica da Camera disbanded. Coincidentally, the ABC also discontinued its Recital series, primarily because 'a lack of subscribers had forced the decision'. ${ }^{94}$ While the ABC series had not focused on larger chamber ensembles, occasional appearances such as the Griller Quartet in 1951 had made an important contribution. ${ }^{95}$ Despite these negative developments, forward-looking aspirations accompanied the opening of Mayne Hall at the University of Queensland in 1973. While the QSO soon presented its specialist Gold Series there, Musica Viva audiences were more gradually coaxed into travelling to Mayne Hall. Fortunately, since the recent 'rise of interest ... has been so spectacular', the organisers - including Donald Munro in dual capacities as the University's Deputy Registrar and Musica Viva branch president - had confidence that Mayne Hall was neither too large nor inaccessible. Rather, the imminent expansion to seven concerts annually was seen as a natural progression. ${ }^{96}$

\section{Conclusion}

The first of my three articles surveying 100 years of Queensland's chamber music began with a discussion of the impact of R. T. Jefferies, who established the 'Monday Popular Concerts' in 1872. As entrepreneur, he experienced the vicissitudes of fluctuating audiences, but laid the foundations for what would become, a full century later, a vibrant chamber music scene. In the intervening years, various models were attempted, including subscription series based around resident performers, mixed programming including exploratory repertoire juxtaposed with canonical composers, and also short-lived sponsorship of a full-time professional ensemble. Some of these strategies were perpetuated at the national level by Musica Viva, and also locally by Musica da Camera. As Musica Viva focused exclusively on visiting ensembles from the 1970s and Musica da Camera ceased operations, other alternatives would soon emerge for Queensland-based musicians. The rapidly expanding tertiary sector began to provide additional avenues for chamber music devotees, as did various regional organisations.

Chamber music practitioners search constantly for a sustainable business model, ideal venues and an audience whose loyalty is assured by wise programming choices and artist selection. My research has shown that the Queensland context has sometimes satisfied all requisite criteria, but also that much success is due to the efforts of individual musicians. The growing diversity of chamber music, through inclusion of ensemble types other than string quartets, is part of the mix, as is the growing realisation that living composers are an essential ingredient. Already in the forty years since this survey ceased in 1972, some healthy if unpredictable changes have occurred, not the least being a questioning of what comprises an ideal venue and presentation format. In hindsight, it may well emerge that chamber music is the most sustainable form of classical music in Queensland into the foreseeable future. 


\section{Endnotes}

1 Peter Roennfeldt, 'Music by the few for the many: Chamber music in colonial Queensland', Queensland Review19(2) (2012), 178-89; and 'Artistic collaboration in challenging times: Chamber music in Queensland, 1901-1950', Queensland Review 20(1) (2013), 69-85.

2 Editorial, 'They shall have music', Courier-Mail [CM], 12 February 1944, 2.

3 'Music — 116,000 ', CM, 25 September 1953, 5.

4 Ernest Briggs, 'They're theatrical orphans': Amateur musicians, actors needing a "home", Sunday Mail [SM], 12 April 1953, 19.

5 Frederic Rogers, 'A Memorial Con? Music loses a friend', Brisbane Telegraph, 19 January 1952, 12.

6 William Lovelock, interview by David Barkla, 29 September 1981, 2.

7 Euterpe, 'Music', Brisbane Courier, 4 June 1879, 3.

8 Briggs, 'Concert reviews - Brisbane', Canon 8(1) (1954), 39.

9 John Ellis, 'Brisbane City Council concerts', Australian Musical News [AMN], 1 June 1955, 12.

10 John Ellis, 'Brisbane City Council Concerts', AMN, 1 October 1956, 25.

11 Musica da Camera, 1957 season brochure.

12 Robert Dalley-Scarlett, 'Tram solos spoilt recital by quartet', CM, 9 May 1957, 9.

13 Roger Covell, 'Quartet fine music asset', CM, 6 November 1957, 13.

14 Frederic Rogers, 'Music group was courageous', Telegraph, 8 May 1958, 19.

15 Roger Covell, 'Reward for heart, mind', CM, 24 July 1958, 6.

16 Roger Covell, 'Light works by orchestra', CM, 18 September 1958, 13.

17 Michael Shmith, 'Richard Goldner - the musical Moses', in Musica Viva Australia - the first fifty years (Sydney: Playbill), p. 6.

18 'Form new musical society for state', CM, 14 March 1956, 9.

19 Roger Covell, 'Does Musica Viva's past guarantee its future?' in Musica Viva Australia, pp. 28-33.

20 William Lovelock, 'Memorable night for Musica Viva', CM, 1 May 1971, 6.

21 Robert Dalley-Scarlett, 'Concert is pleasing', CM, 17 September 1957, 8.

22 Robert Dalley-Scarlett, 'Musica Viva's standard held', CM, 21 October 1958, 21.

23 Roger Covell, 'A new demand for home-made music', CM, 31 March 1960, 2.

24 Ernest Briggs, 'Concert reviews - Brisbane', Canon 9(11) (1956), 341.

25 Ernest Briggs, 'Concert reviews - Brisbane', Canon 10(3) (1956), 105.

26 Ernest Briggs, 'Concert reviews - Brisbane', Canon 10(10) (1957), 348.

27 Ernest Briggs, 'Concert reviews - Brisbane', Canon 11(4) (1957), 116.

28 'Musica Viva', Canon February 1960, 156-7.

29 Frederic Rogers, 'Brisbane DOES like chamber music', SM, 22 March 1959, 6.

30 Roger Covell, Musica Viva Australia, p. 32.

31 Ernest Briggs, 'Concert reviews - Brisbane', Canon 10(10) (1957), 348.

32 Ernest Briggs, 'Concerts - Brisbane', Canon 11(12) (1958), 388.

33 Musica da Camera, 1959 season brochure.

34 Roger Covell, 'Rewarding concert', CM, 14 May 1959, 13. 
35 Roger Covell, 'Schumann a reward', CM, 6 August 1959, 18.

36 William Lovelock, 'Broke new ground at recital', CM, 25 September 1959, 20.

37 Music da Camera, 1960 season brochure.

38 William Lovelock, 'Concert policy praised', CM, 11 August 1960, 12.

39 William Lovelock, 'Musica da Camera’s attractive recital', CM, 15 September 1960, 15.

40 Roger Covell, 'Concert proved out of routine', CM, 27 June 1960, 6.

41 William Lovelock, 'Variable style at concert', CM, 18 May 1961, 11.

42 'Novel Czech trio in Sunday concert', CM, 27 October 1961, 14.

43 William Lovelock, 'Credit due to artists', CM, 27 July 1961, 25.

44 'A quick lesson from composer', CM, 17 June 1961, 17.

45 John Villaume, 'Colour in big night at concert', CM, 20 July 1962, 11.

46 John Villaume, 'A fitting climax for Da Camera', CM, 1 November 1963, 11.

47 For details of Sedivka's Brisbane years, see Elinor Morrisby, Up is down: A life of violinist Jan Sedivka (Melbourne: Lyrebird Press, 2008).

48 'Top marks to string trio', CM, 25 June 1962, 7.

49 William Lovelock, 'New quartet is very creditable', CM, 21 July 1966, 6.

50 William Lovelock, 'Undue tension in Musica da Camera', CM, 20 October 1966, 10.

51 William Lovelock, 'Their concert best yet', CM, 27 April 1967, 6.

52 William Lovelock, 'Efficient and balanced', CM, 6 July 1967, 6.

53 Lovelock, 'Humanity, emotion in three sonatas', CM, 5 October 1967, 6.

54 William Lovelock, 'Quartet greatly improved', CM, 11 August 1965, 6.

55 William Lovelock, 'More than a "happening"', CM, 18 October 1971, 6.

56 William Lovelock, 'Swiss Trio's music "full of vitality”, CM, 27 October 1970, 6.

57 William Lovelock, 'Performance of artistic delight', CM, 10 April 1972, 6.

58 'Musica Viva Younger Set', Canon 11(4) (1957), 123.

59 William Lovelock, 'Chamber music success', CM, 6 March 1961, n.p.

60 'Music goes from home to home', CM, 17 May 1962, 17.

61 William Lovelock, 'Unusual interest in this Bach', CM, 9 April 1970, 8.

62 William Lovelock, 'Musical festival a great success', CM, 7 May 1968, 6.

63 David Rowbotham, 'Group's first arts festival on coast', CM, 21 August 1970, 6.

64 Personal interview with Rodney Jacobsen, 10 March 2010.

65 'Instrument for concert is rare', CM, 24 June 1960, 7.

66 John Villaume, 'Quartet shows it can happen here', CM, 24 July 1964, 10.

67 William Lovelock, 'Commend choice, but ..., CM, 23 October 1964, 10.

68 John Villaume, 'Bach rare concert', CM, 27 July 1967, 6.

69 William Lovelock, 'Undue tension in Musica da Camera', CM, 20 October 1966, 10.

70 William Lovelock, 'Happy mood at music recital', CM, 28 May 1971, 6.

71 William Lovelock, 'Recital produced continued artistry', CM, 18 April 1967, 8.

72 William Lovelock, 'Performer of attainment', CM, 27 July 1971, 6.

73 John Villaume, 'Wind players held interest', CM, 13 June 1968, 6.

74 William Lovelock, ' Concert deserves support', CM, 7 August 1969, 6. 
75 William Lovelock, 'Concert enterprise was as expected', CM, 14 September 1972, 8.

76 William Lovelock, 'Concert as good as their best', CM, 23 October 1969, 6.

77 William Lovelock, 'Happy mood at music recital', CM, 28 May 1971, 6.

78 Enid Tardent, 'Music notes', Catholic Leader, 19 November 1972, 19.

79 William Lovelock, 'Quintet in interesting programme', CM, 26 June 1969, 6.

80 '\$15,500 gift for cultural bodies', CM, 18 March 1969, 6.

81 'Lunch hour recital', Morning Bulletin (Rockhampton), 11 August 1950, 3.

82 'Lunch hour recitals', Morning Bulletin, 18 July 1952, 7.

83 'A Delius sonata recital', Townsville Daily Bulletin [TDB], 10 May 1951, 3.

84 TDB, 15 September 1954, 2.

85 TDB, 13 March 1954, 2.

86 'Chamber music concert', TDB, 6 October 1969, 7.

87 'Apollo', 'Gloria Foley Trio delights audience', Warwick Daily News, 20 May 1958, 5.

88 V. H., 'Visitors in concert', Toowoomba Chronicle [TC], 25 October 1958, 2.

89 Mary Childe, 'Chamber music recital', TC, 13 April 1964, 2.

90 E. S., 'Concert "unusual” but "most entertaining”', TC, 20 June 1966, 6.

91 For more detail, see Roennfeldt, 'Artistic collaboration', 77-80.

92 William Lovelock, 'Civic concert had clarity and colour', CM, 31 March 1969, 6.

93 William Lovelock, 'Concert strings excellent', CM, 8 April 1968, 8.

94 David Rowbotham, 'ABC to end recital concert series', CM, 6 October 1972, 2.

95 Ernest Briggs, 'Concert Reviews - Brisbane', Canon 4(10) (1951), 494.

96 David Rowbotham, 'Pop music without the "rabies" - “chamber" music in 1000-seaters', CM, 22 February 1973, 4. 